Article

\title{
Incidence, Antimicrobial Susceptibility, and Toxin Genes Possession Screening of Staphylococcus aureus in Retail Chicken Livers and Gizzards
}

\author{
Lubna S. Abdalrahman and Mohamed K. Fakhr * \\ Department of Biological Science, The University of Tulsa, Tulsa, OK 74104, USA; \\ E-Mail: Lubna-abdalrahman@utulsa.edu \\ * Author to whom correspondence should be addressed; E-Mail: Mohamed-fakhr@utulsa.edu; \\ Tel.: +1-918-631-2197; Fax: +1-918-631-2762.
}

Academic Editor: Christopher J. Smith

Received: 18 August 2014 / Accepted: 13 April 2015 / Published: 21 April 2015

\begin{abstract}
Few recent outbreaks in Europe and the US involving Campylobacter and Salmonella were linked to the consumption of chicken livers. Studies investigating Staphylococcus aureus in chicken livers and gizzards are very limited. The objectives of this study were to determine the prevalence, antimicrobial resistance, and virulence of $S$. aureus and MRSA (Methicillin-Resistant Staphylococcus aureus) in retail chicken livers and gizzards in Tulsa, Oklahoma. In this study, 156 chicken livers and 39 chicken gizzards samples of two brands were collected. While one of the brands showed very low prevalence of $1 \%(1 / 100)$ for S. aureus in chicken livers and gizzards, the second brand showed prevalence of $37 \%$ (31/95). No MRSA was detected since none harbored the mecA or mecC gene. Eighty seven $S$. aureus isolates from livers and 28 from gizzards were screened for antimicrobial resistance to 16 antimicrobials and the possession of 18 toxin genes. Resistance to most of the antimicrobials screened including cefoxitin and oxacillin was higher in the chicken gizzards isolates. While the prevalence of enterotoxin genes seg and sei was higher in the gizzards isolates, the prevalence of hemolysin genes $h l a, h l b$, and $h l d$ was higher in the livers ones. The lucocidin genes $l u k E-l u k D$ was equally prevalent in chicken livers and gizzards isolates. Using spa typing, a subset of the recovered isolates showed that they are not known to be livestock associated and, hence, may be of a human origin. In conclusion, this study stresses the importance of thorough cooking of chicken livers and gizzards since it might contain multidrug resistant enterotoxigenic S. aureus. To
\end{abstract}


our knowledge this is the first study to specifically investigate the prevalence of $S$. aureus in chicken livers and gizzards in the US.

Keywords: Staphylococcus aureus; antibiotic resistance; toxins; toxin genes; prevalence; chicken livers; chicken gizzards; antimicrobials; foodborne pathogens; retail meat

\section{Introduction}

Recent studies highlighted the importance of chicken livers as a food safety hazard. A US study found that $77 \%$ of retail chicken livers and $33 \%$ of chicken gizzards were contaminated with Campylobacter [1]. Several recent outbreaks involving Campylobacter from poultry livers have occurred in Europe [2-5] and in the US [6,7]. A US outbreak of Salmonella Heidelberg was linked to Kosher Broiled Chicken Livers [8]. One study - as a part of a larger study on retail raw chicken meat throughout Japan — reported a high prevalence of S. aureus in chicken livers (63.8\%) and chicken gizzards (58.1\%) after enrichment [9]. Another study in Turkey reported 9/30 of chicken giblets (30\%) to be positive for the bacterium [10].

Staphylococcus aureus is the fifth pathogen causing domestically acquired foodborne illnesses annually in the United States [11] and its food poisoning is an important cause of food-borne diseases worldwide [12]. Several staphylococcal enterotoxins and enterotoxin-like superantigens have been described [13-15]. Staphylococcal food poisoning is an intoxication resulting from the consumption of food that has been contaminated with the toxin itself and most of its symptoms are self-limiting within one to two days after consumption [16]. Staphylococcus aureus has the ability to destroy red blood cells by producing three types of hemolysins, known as alpha, beta and delta toxins [17]. The beta hemolysin gene is considered dangerous since it encodes the beta toxins that have the ability to inhibit the ciliary activity of human lungs and cornea [18-20].

Most studies in the literature specifically reporting prevalence of MRSA (Methicillin-Resistant Staphylococcus aureus) in food animals were conducted in pigs [21-24]. S. aureus and MRSA have been also isolated and was highly prevalent in poultry in the Netherlands [25]. It was also detected in retail chicken meat in Japan [9]. In the last few years, few studies were conducted to determine the prevalence of $S$. aureus and MRSA in retail meats in several states in the United States that includes North Dakota [26,27], Georgia [28], Minnesota, and New Jersey [29], Iowa [30], Detroit, Michigan [31], Maryland [32] and Louisiana, [33]. Only few of those studies included data from poultry such as ground turkey [32], chicken and/or turkey [26,27,30,31]. While most studies conducted in Europe identified MRSA isolated from retail meats as belonging to Livestock associated MRSA strains (LAMRSA), the majority of MRSA isolates detected in the US retail meats were human associated strains except few that were LA-MRSA and were mostly reported in pork meat. So, opposite to the case in Europe, US retail meats when contaminated with MRSA the origin is most likely from human handling the meat products.

Studies investigating the prevalence of $S$. aureus and MRSA in chicken livers and gizzards are very limited [9] and to our knowledge none is available to date from the US. Chicken livers in particular are usually undercooked to preserve taste and texture which can be risky if contaminated with enterotoxin 
producing strains of $S$. aureus specially that most of these enterotoxins are heat stable. The objectives of this study were to determine the prevalence of $S$. aureus and MRSA in retail chicken livers and gizzards collected in Tulsa, Oklahoma and to characterize the recovered isolates for their antimicrobial susceptibility and possession of toxin genes. To our knowledge this study is the first to specifically investigate the prevalence of $S$. aureus in chicken livers and gizzards in the US.

\section{Experimental Section}

\subsection{Isolation of Staphylococcus aureus from Retail Chicken Livers and Gizzards}

Chicken livers and gizzards samples were collected from several different grocery stores in the Tulsa, Oklahoma area for a period of six months starting January of 2010. A total of 195 chilled retail chicken liver and chicken gizzard samples were used in this study (156 chicken livers and 39 chicken Gizzards) (Table 1). Meat samples were purchased from nine grocery stores that belong to six different franchises chains at variable locations in the city. The chicken livers and gizzards belonged to two major brands, which are designated brand A and brand B (Table 1). Samples were selected to be as variable as possible with different expiration and production dates. Chicken livers and gizzards samples were added to $10 \mathrm{~mL}$ of buffered peptone water (BPW) (BPW; EMD, Gibbstown, NJ, USA) in sterile plastic bags (VWR Scientific, Radnor, PA, USA) and massaged by hand for approximately 5 min. Ten milliliters was then transferred from the bag and added to $10 \mathrm{~mL}$ of enrichment broth of $2 \times$ Trypticase Soy Broth with $10 \%$ sodium chloride and $1 \%$ sodium pyruvate, then incubated at $37{ }^{\circ} \mathrm{C}$ for 24 h. A loopful was then streaked to Baird Parker (BP) selective media plates and incubated at $37{ }^{\circ} \mathrm{C}$ for $48 \mathrm{~h}$ [33]. Four suspected $S$. aureus colonies (those that have black colonies surrounded by 2 to 5 mm clear zones) were selected and streaked to Trypticase Soy Agar (TSA) plates and subcultured for confirmation on MSA (Mannitol Salt Agar) plates. Pure prospective S. aureus cultures were kept at -80 ${ }^{\circ} \mathrm{C}$ until PCR confirmation.

Table 1. PCR primers and their references for Staphylococcus aureus and MRSA identification.

\begin{tabular}{|c|c|c|c|c|}
\hline Gene & Size (bp) & Primer sequences $\left(5^{\prime}-3^{\prime}\right)$ & Bacterium & References \\
\hline $\begin{array}{l}S a 4221-1 \\
S a 4221-2\end{array}$ & 108 & $\begin{array}{l}\text { AAT CTT TGT CGG TAC ACG ATA TTC TTC ACG } \\
\text { CGT AAT GAG ATT TCA GTA GAT AAT ACA ACA }\end{array}$ & S. aureus & {$[34]$} \\
\hline $\begin{array}{l}m e c A-F \\
m e c A-R\end{array}$ & 312 & $\begin{array}{c}\text { GTT GTA GTT GTC GGG TTT GG } \\
\text { CTT CCA CAT ACC ATC TTC TTT AAC }\end{array}$ & $M R S A$ & {$[21]$} \\
\hline $\begin{array}{l}\text { mecAlF } \\
\text { mecA2R }\end{array}$ & 533 & $\begin{array}{l}\text { AAA ATC GAT GGT AAA GGT TGG C } \\
\text { AGT TCT GCA GTA CCG GAT TTG C }\end{array}$ & $M R S A$ & [35] \\
\hline $\begin{array}{l}\text { MecHomFW } \\
\text { MecHomRV }\end{array}$ & 356 & $\begin{array}{c}\text { TCA CCA GGT TCA AC[Y] CAA AA } \\
\text { CCT GAA TC[W] GCT AAT AAT ATT TC }\end{array}$ & $M R S A$ & {$[36]$} \\
\hline $\begin{array}{l}\text { mecAM10/0061 F1 } \\
\text { mecAM10/0061 R1 }\end{array}$ & 1800 & $\begin{array}{l}\text { CCA GAT ATA GTA GCA TTA TA } \\
\text { AAA GAT GAC GAT ATT GAG }\end{array}$ & $M R S A$ & {$[37]$} \\
\hline
\end{tabular}

\subsection{DNA Extraction}

DNA was extracted from the prospective $S$. aureus strains using the single cell lysing buffer (SCLB) method [38]. One day old colonies were picked and suspended in $40 \mu \mathrm{L}$ of single cell lysing 
buffer (SCLB) solution (1.0 mL of TE buffer (10 mM Tris-HCL and $1 \mathrm{mM}$ EDTA) and $10 \mu 1$ of 5 $\mathrm{mg} / \mathrm{mL}$ proteinase $\mathrm{K}$ ) in a $0.2 \mathrm{~mL}$ microtube. In a thermocycler, bacterial cells were lysed by initial incubation at $80{ }^{\circ} \mathrm{C}$ for $10 \mathrm{~min}$, followed by $55^{\circ} \mathrm{C}$ for $10 \mathrm{~min}$, and then $95{ }^{\circ} \mathrm{C}$ for $10 \mathrm{~min}$ [38]. DNA extracted by the above mentioned method was stored at $-20^{\circ} \mathrm{C}$ until used as a DNA template for PCR.

\subsection{PCR Identification}

A multiplex PCR reaction was used to identify the isolated suspected $S$. aureus by using specific primers for S. aureus and MRSA to amplify a $108 \mathrm{bp}$ and a $312 \mathrm{bp}$ fragments respectively (Table 4). Twenty microliters PCR reactions, which included $10 \mu \mathrm{L}$ of Qiagen Master Mix (Qiagen Inc., Valencia, CA, USA), $4 \mu \mathrm{L}$ of sterile water (Qiagen), $1 \mu \mathrm{L}$ of each forward and reverse primer (IDT, Coralville, IA, USA), and $2 \mu \mathrm{L}$ of DNA template, were performed. The PCR protocol was as follows: initial denaturing at $95{ }^{\circ} \mathrm{C}$ for $5 \mathrm{~min}$ (followed by 35 cycles of denaturing at $95{ }^{\circ} \mathrm{C}$ for $1 \mathrm{~min}$, annealing at $55^{\circ} \mathrm{C}$ for $1 \mathrm{~min}$, and extension at $72{ }^{\circ} \mathrm{C}$ for $1 \mathrm{~min}$ ) and ending with extension at $72{ }^{\circ} \mathrm{C}$ for $10 \mathrm{~min}$. PCR amplicons were subjected to agarose gel electrophoresis and DNA bands were visualized and recorded using a gel documentation system. Isolates showing resistance to cefoxitin and/oxacillin were subjected to PCR confirmation using a second set of MRSA primers that amplify a 533 bp mecA fragment and two other variant MRSA mecA primer sets (also known as mecC) that amplify $356 \mathrm{bp}$ and $1800 \mathrm{bp}$ fragments to confirm the MRSA phenotype (Table 1).

\subsection{Antimicrobial Susceptibility Testing}

A total of $115 \mathrm{~S}$. aureus recovered isolates (87 chicken liver isolates and 28 chicken gizzard isolates) were subjected to antimicrobial resistance profiling against sixteen different antimicrobials that belong to ten different antibiotic classes (Table 2). Isolates were grown on Mueller-Hinton (MH) agar (Difco) and incubated for $48 \mathrm{~h}$ at $37{ }^{\circ} \mathrm{C}$. Cultures were then added to Mueller-Hinton broth (Difco), adjusted to turbidity equal to a $0.5 \mathrm{McFarland}$ standard, and inoculated onto 6-inch $\mathrm{MH}$ agar plates supplemented with the appropriate antimicrobial at different concentrations (Table 2) including the breakpoint established for each antimicrobial according to the Clinical and Laboratory Standards Institute (CLSI) when available [39]. Plates were then incubated at $37{ }^{\circ} \mathrm{C}$ for $48 \mathrm{~h}$ and results were read for growth or no growth and denoted as resistant or susceptible, respectively according to the breakpoints for each of the tested antimicrobials (Table 2). 
Table 2. A list of the 16 antimicrobials, their classes, concentrations used for susceptibility testing, and the breakpoints used for each antimicrobial.

\begin{tabular}{|c|c|c|c|c|c|}
\hline Antimicrobial Class & Antimicrobials & $\begin{array}{c}\text { Conc. } 1 * \\
(\mu \mathrm{g} / \mathrm{mL})\end{array}$ & $\begin{array}{c}\text { Conc. } 2(\mu \mathrm{g} / \mathrm{mL}) \\
\text { (Break point) }\end{array}$ & $\begin{array}{l}\text { Conc. } 3 \\
(\mu \mathrm{g} / \mathrm{mL}) \\
\end{array}$ & $\begin{array}{r}\text { Conc. } 4 \\
(\mu \mathrm{g} / \mathrm{mL})\end{array}$ \\
\hline \multirow{4}{*}{$\beta$-Lactams } & penicillin & 0.125 & 0.25 & 0.5 & 1 \\
\hline & ampicillin & 0.25 & 0.5 & 1 & 2 \\
\hline & oxacillin $+2 \% \mathrm{Nacl}$ & 2 & 4 & 8 & 16 \\
\hline & cefoxitin $+2 \% \mathrm{Nacl}$ & 4 & 8 & 16 & 32 \\
\hline \multirow{2}{*}{ Tetracyclines } & tetracycline & 8 & 16 & 32 & 64 \\
\hline & doxycycline & 8 & 16 & 32 & 64 \\
\hline \multirow{2}{*}{ Macrolides } & azithromycin & 4 & 8 & 16 & 32 \\
\hline & erythromycin & 4 & 8 & 16 & 32 \\
\hline \multirow{2}{*}{ Aminoglycosides } & kanamycin & 32 & 64 & 128 & 256 \\
\hline & gentamicin & 8 & 16 & 32 & 64 \\
\hline Fluoroquinolones & ciprofloxacin & 2 & 4 & 8 & 16 \\
\hline Lincosamides & clindamycin & 2 & 4 & 8 & 16 \\
\hline Phenicols & chloramphenicol & 16 & 32 & 64 & 128 \\
\hline Glycopeptides & vancomycin & 16 & 32 & 64 & 128 \\
\hline Rifamycines & rifampin & 2 & 4 & 8 & 16 \\
\hline Sulfonamides & trimethoprim/sulfamethoxazole & $2 / 38$ & $4 / 76$ & $8 / 152$ & $16 / 304$ \\
\hline
\end{tabular}

\subsection{Detection of Toxin Genes}

A total of 115 Staphylococcus aureus isolates (87 chicken liver isolates and 28 chicken gizzard isolates) were screened for eighteen different toxin genes that belong to six different toxin gene groups (Table 3). Multiplex PCR was used to detect 18 different toxin genes of $S$. aureus isolates that include enterotoxins, toxic shock syndrome toxin 1, exfoliative toxins, leucocidins, Panton-Valentine leucocidin (PVL), and hemolysins (Table 3). Three multiplex reactions (A, B, and C), each of which included six toxin genes, were performed (Table 3). The multiplex PCR targeting the toxin genes were performed in a $20 \mu \mathrm{L}$ reaction solution that contained $10 \mu \mathrm{L}$ of Green Master Mix (Promega), $2 \mu \mathrm{L}$ of sterile water, $2 \mu \mathrm{L}$ of the DNA template and $0.5 \mu \mathrm{L}$ of each of the toxin gene primers. The PCR protocol included an initial denaturation at $95{ }^{\circ} \mathrm{C}$ for $5 \mathrm{~min}$, followed by 30 cycles of denaturation (94 ${ }^{\circ} \mathrm{C}$ for $1 \mathrm{~min}$ ), annealing $\left(57^{\circ} \mathrm{C}\right.$ for $\left.1 \mathrm{~min}\right)$, and extension $\left(72{ }^{\circ} \mathrm{C}\right.$ for $\left.1 \mathrm{~min}\right)$, ending with an extension at $72{ }^{\circ} \mathrm{C}$ for $7 \mathrm{~min}$. PCR amplicons were subjected to agarose gel electrophoresis and DNA bands were visualized and recorded using a gel documentation system. The expected amplicon band sizes of $S$. aureus toxin genes are shown in Table 3. Several representative amplicons of each positive toxin were sequenced in house using the same amplifying primers to confirm PCR accuracy. 
Table 3. Multiplex PCR primers, reaction sets, references, and toxin groups for the screened toxin genes.

\begin{tabular}{|c|c|c|c|c|}
\hline Toxin Gene (Toxin group) & Size (bp) & Primer sequences $\left(5^{\prime}-3^{\prime}\right)$ & $\begin{array}{l}\text { Multiplex PCR } \\
\text { reaction set }\end{array}$ & References \\
\hline sea (Enterotoxins) & 521 & $\begin{array}{c}\text { GCA GGG AAC AGC TTT AGG C } \\
\text { GTT CTG TAG AAG TAT GAA ACA CG }\end{array}$ & A & [40] \\
\hline seb-sec (Enterotoxins) & 665 & $\begin{array}{c}\text { ATG TAA TTT TGA TAT TCG CAG TG } \\
\text { TGC AGG CAT CAT ATC ATA CCA }\end{array}$ & A & [40] \\
\hline $\sec$ (Enterotoxins) & 284 & $\begin{array}{c}\text { CTT GTA TGT ATG GAG GAA TAA CAA } \\
\text { TGC AGG CAT CAT ATC ATA CCA }\end{array}$ & A & [40] \\
\hline sed (Enterotoxins) & 385 & $\begin{array}{c}\text { GTG GTG AAA TAG ATA GGA CTG C } \\
\text { ATA TGA AGG TGC TCT GTG G } \\
\end{array}$ & A & [40] \\
\hline see (Enterotoxins) & 171 & $\begin{array}{c}\text { TAC CAA TTA ACT TGT GGA TAG AC } \\
\text { CTC TTT GCA CCT TAC CGC }\end{array}$ & A & [40] \\
\hline seg (Enterotoxins) & 328 & $\begin{array}{l}\text { CGT CTC CAC CTG TTG AAG G } \\
\text { CCA AGT GAT TGT CTA TTG TCG }\end{array}$ & $\mathrm{A}$ & [40] \\
\hline $\operatorname{seh}$ (Enterotoxins) & 359 & $\begin{array}{l}\text { CAA CTG CTG ATT TAG CTC AG } \\
\text { GTC GAA TGA GTA ATC TCT AGG }\end{array}$ & B & [40] \\
\hline sei (Enterotoxins) & 466 & $\begin{array}{c}\text { CAA CTC GAA TTT TCA ACA GGT AC } \\
\text { CAG GCA GTC CAT CTC CTG } \\
\end{array}$ & $\mathrm{B}$ & [40] \\
\hline sej (Enterotoxins) & 142 & $\begin{array}{l}\text { CAT CAG AAC TGT TGT TCC GCT AG } \\
\text { CTG AAT TTT ACC ATC AAA GGT AC }\end{array}$ & B & [40] \\
\hline $\begin{array}{l}\text { tst (Toxic Shock Syndrome } \\
\text { Toxin 1) }\end{array}$ & 560 & $\begin{array}{c}\text { GCT TGC GAC AAC TGC TAC AG } \\
\text { TGG ATC CGT CAT TCA TTG TTA A }\end{array}$ & B & [40] \\
\hline eta (Exfoliative toxins) & 93 & $\begin{array}{l}\text { GCA GGT GTT GAT TTA GCA TT } \\
\text { AGA TGT CCC TAT TTT TGC TG }\end{array}$ & B & [41] \\
\hline$e t b$ (Exfoliative toxins) & 226 & $\begin{array}{c}\text { ACA AGC AAA AGA ATA CAG CG } \\
\text { GTT TTT GGC TGC TTC TCT TG } \\
\end{array}$ & B & [41] \\
\hline $\begin{array}{l}\text { lukS-lukF (Panton-Valentine } \\
\quad \text { leucocidin }(\mathrm{PVL}))\end{array}$ & 433 & $\begin{array}{c}\text { ATC ATT AGG TAA AAT GTC TGG ACA } \\
\text { TGA TCC A } \\
\text { GCA TCA AST GTA TTG GAT AGC AAA } \\
\text { AGC }\end{array}$ & $\mathrm{C}$ & [42] \\
\hline lukE-lukD (Leucocidin) & 269 & $\begin{array}{l}\text { TGA AAA AGG TTC AAA GTT GAT ACG AG } \\
\text { TGT ATT CGA TAG CAA AAG CAG TGC A }\end{array}$ & $\mathrm{C}$ & [42] \\
\hline$l u k M$ (Leucocidin) & 780 & $\begin{array}{c}\text { TGG ATG TTA CCT ATG CAA CCT AC } \\
\text { GTT CGT TTC CAT ATA ATG AAT CAC TAC }\end{array}$ & $\mathrm{C}$ & [42] \\
\hline hla (Hemolysins) & 209 & $\begin{array}{l}\text { CTG ATT ACT ATC CAA GAA ATT CGA TTG } \\
\text { CTT TCC AGC CTA CTT TTT TAT CAG T }\end{array}$ & $\mathrm{C}$ & {$[42]$} \\
\hline$h l b$ (Hemolysins) & 309 & $\begin{array}{l}\text { GTG CAC TTA CTG ACA ATA GTG C } \\
\text { GTT GAT GAG TAG CTA CCT TCA GT }\end{array}$ & $\mathrm{C}$ & [42] \\
\hline hld (Hemolysins) & 111 & $\begin{array}{l}\text { AAG AAT TTT TAT CTT AAT TAA GGA AGG } \\
\text { AGT G } \\
\text { TTA GTG AAT TTG TTC ACT GTG TCG A }\end{array}$ & $\mathrm{C}$ & [42] \\
\hline
\end{tabular}




\subsection{Molecular Typing Using spa Genotyping}

A subset of the recovered Staphylococcus aureus isolates were subjected to molecular typing using spa typing. Molecular typing using spa was done according to published primers and protocols [43] and spa types were assigned using the BioNumerics Software (Applied Math, Austin, TX, USA) through the Ridom Spa Server.

\section{Results and Discussion}

\subsection{Prevalence of Staphylococcus aureus and MRSA in Chicken Livers and Gizzards}

A total of 195 chilled retail chicken liver and chicken gizzard samples were purchased from several Tulsa area grocery stores starting January 2010 for a period of 6 months. The number of chicken liver samples was 156 and the number of chicken gizzard samples was 39 (Table 1). The chicken livers and gizzards collected in this study belonged to two major brands, which were designated brand A and brand B (Table 4). As shown in Table 4, the overall prevalence of $S$. aureus in chicken livers and gizzards including the two brands together was 36/195 (18.5\%). While 27/156 (17.3\%) of chicken livers were contaminated with S. aureus, 9/39 (23.1\%) of chicken gizzards were positive for the bacterium. The prevalence of $S$. aureus in brand A chicken livers was 26/71 (36.6\%) while it was 9/24 $(37.5 \%)$ in chicken gizzards of the same brand (Table 1). Only one out of 85 chicken liver samples $(1.2 \%)$ of brand B was positive for $S$. aureus and none of the chicken gizzards of this brand was positive for $S$. aureus. No isolates of chicken livers and gizzards were positive for MRSA since none of them carried mecA or mecC genes.

Even though the overall prevalence of $S$. aureus in chicken livers and gizzards was 36/195 (18.5\%) in our study, the $36.6 \%$ and the $37.5 \%$ prevalence in brand A chicken livers and gizzards respectively is alarming (Table 4). While there were no available studies in the literature that specifically determined the prevalence of $S$. aureus in chicken livers and gizzards, a study in Turkey reported contamination in 9/30 (30\%) of chicken giblets as a part of a larger study on chicken meat [10]. A second study in Japan reported a higher prevalence of $S$. aureus in chicken livers $(63.8 \%)$ and chicken gizzards (58.1\%) after enrichment while it was $47.9 \%$ and $22.6 \%$ respectively before enrichment [9]. The higher prevalence in the Japanese study might be due to differences between the US and the Japanese retail poultry markets. It can also be due to the methods used for identification since the Japanese study used only biochemical tests for identification of the S. aureus strains while molecular identification was used in our study. S. aureus was isolated from $56 \%$ of ground turkey collected from Maryland, USA [32] and was found in 25\% of retail chicken in Detroit, Michigan where 3.9\% were MRSA [31]. In another study in Iowa, $17.8 \%$ of retail chicken was contaminated with S. aureus [30], while in North Dakota a higher prevalence of S. aureus (67.6\%) in retail chicken was reported [26].

The big difference between the overall prevalence of $S$. aureus in chicken livers and gizzards in brand A in our study (36.8\%) and only $1 \%$ in brand B (Table 4) might be due to the difference in food safety and microbiology quality control handling protocols at the two production companies. While not conclusive, this data might suggest that chicken livers and gizzards contamination with $S$. aureus most probably occurs during handling at the slaughter house or at the retail packaging step. 
Table 4. Prevalence of Staphylococcus aureus in the 195 collected chicken liver and gizzards samples.

\begin{tabular}{|c|c|c|c|c|c|c|c|c|}
\hline \multicolumn{9}{|c|}{ Prevalence of Staphylococcus aureus } \\
\hline \multicolumn{3}{|c|}{ Chicken Livers } & \multicolumn{3}{|c|}{ Chicken Gizzards } & \multicolumn{3}{|c|}{ Chicken Livers and Gizzards } \\
\hline $\begin{array}{c}\text { Brand A } \\
n p / n * \\
(\%)\end{array}$ & $\begin{array}{c}\text { Brand B } \\
n p / n \\
(\%)\end{array}$ & $\begin{array}{c}\text { Total } \\
n p / n \\
(\%) \\
\end{array}$ & $\begin{array}{c}\text { Brand A } \\
n p / n \\
(\%)\end{array}$ & $\begin{array}{c}\text { Brand B } \\
n p / n \\
(\%)\end{array}$ & $\begin{array}{l}\text { Total } \\
n p / n \\
(\%) \\
\end{array}$ & $\begin{array}{c}\text { Brand A } \\
n p / n \\
(\%)\end{array}$ & $\begin{array}{c}\text { Brand B } \\
n p / n \\
(\%)\end{array}$ & $\begin{array}{c}\text { Total } \\
n p / n \\
(\%) \\
\end{array}$ \\
\hline $\begin{array}{l}26 / 71 \\
(36.6)\end{array}$ & $\begin{array}{l}1 / 85 \\
(1.2)\end{array}$ & $\begin{array}{c}27 / 156 \\
(17,3)\end{array}$ & $\begin{array}{c}9 / 24 \\
(375)\end{array}$ & $\begin{array}{c}0 / 15 \\
(0)\end{array}$ & $\begin{array}{c}9 / 39 \\
(23,1)\end{array}$ & $\begin{array}{l}35 / 95 \\
(36.8)\end{array}$ & $\begin{array}{c}1 / 100 \\
\text { (1) }\end{array}$ & $\begin{array}{r}36 / 195 \\
(18.5)\end{array}$ \\
\hline
\end{tabular}

* np: number of positive samples, $n$ : number of samples collected.

\subsection{Antimicrobial Susceptibility of the Recovered Isolates}

A total of 115 Staphylococcus aureus isolates (87 chicken liver isolates and 28 chicken gizzard isolates) were subjected to antimicrobial resistance profiling against sixteen different antimicrobials that belong to ten different antibiotic classes (Tables 2 and 5). As shown in Table 5, the percentage of resistance of the $115 \mathrm{~S}$. aureus isolates from chicken livers and gizzards to the sixteen tested antimicrobials were as follow: ampicillin (88.9\%), tetracycline (71.3\%), doxycycline (63.5\%), penicillin $(60.9 \%)$, erythromycin $(45.2 \%)$, azithromycin $(40,9 \%)$, vancomycin $(39.1 \%)$, oxacillin with $2 \% \mathrm{NaCl}(32.2 \%)$, ciprofloxacin $(29.6 \%)$, trimethoprim/sulfamethazole (24.3\%), rifampin (23.5\%), cefoxitin with $2 \% \mathrm{NaCl}(19.1 \%)$, clindamycin (12.2\%), kanamycin (12.2\%), chloramphenicol (10.4\%), and gentamicin (10.4\%). As shown in Table 5, the percentage of resistance to the sixteen tested antimicrobials varied between chicken livers and chicken gizzards isolates. The percentage of resistance found in the chicken gizzards was higher than chicken livers isolates for the following 10 antimicrobials: azithromycin, ciprofloxacin, oxacillin, cefoxitin, tetracycline, vancomycin, doxycycline, penicillin, kanamycin, and erythromycin (Table 5). On the other hand, for gentamycin, ampicillin, trimethoprim/sulfamrthoxazole, clindamycin, rifampin, chloramphenicol the chicken livers isolates showed a higher resistance (Table 5). This variability in antimicrobial resistance between isolates from chicken livers and gizzards might be attributed to the concentration of different antimicrobials in the liver and/or the fact that chicken gizzards often have more fats that would make some highly lipid soluble antimicrobials like azithromycin get to higher concentrations in the gizzards. Overall 35/115 (30\%) of the screened isolates from chicken livers and gizzards were multidrug resistant to more than seven antimicrobials (data not shown) which is worrisome.

Resistance to vancomycin was relatively high in isolates from chicken livers and gizzards in our study (Table 5).Vancomycin Resistant Enterococcus faecium (VRE) was previously reported in swine in Michigan, USA and was thought to be widespread despite the historical absence of the use of agricultural glycopeptides like avoparcin. Screening our phenotypically vancomycin strains for the presence of the vanA gene is currently underway as a part of a larger study focusing on vancomycin resistant $S$. aureus strains isolated from various US retail meats. Chicken livers and gizzards isolates in our study were highly resistant to ampicillin, tetracycline, doxycycline, penicillin, and erythromycin (Table 5). The literature is lacking data about antimicrobial resistance of S. aureus strains isolated from chicken livers and gizzards. One study in Turkey [10] reported that $S$. aureus isolates from chicken giblets were resistant to penicillin $\mathrm{G}(22.2 \%)$ and erythromycin (33.3\%). S. aureus recovered strains in 
our study that showed resistance to cefoxitin and/or oxacillin (highly prevalent in chicken gizzards as shown in Table 5) were subjected to additional PCR protocols to check for the presence of a mecA homologue (Table 1). None of these isolates showed the presence of mecA gene or it homologues (mecC). Phenotypic MRSA isolates that do not harbor the mecA gene were reported [32,44]. This might be due to over production of Beta-lactamase enzymes or the presence of a variant mecA gene that does not amplify with the known PCR primers. The recent advancement in whole genome sequencing through next generation sequencing can help identifying such homologues.

The high number of multidrug resistant $S$. aureus detected in our study is alarming. It raises concerns about inappropriate practices including the use of antimicrobials as growth promotors in food animal production and the frequent use of antimicrobials in poultry husbandry. Genes coding for antimicrobial resistance can move through horizontal gene transfer to clinical pathogenic strains and contribute to the creation of superbugs. Death in hospitals are often attributed to sepsis resulting from infections caused by multidrug resistant pathogens like MRSA, Pseudomonas aeruginosa or Candida albicans rather than the original cause of the hospitalization.

Table 5. Antimicrobial resistance of the 115 Staphylococcus aureus chicken liver and gizzard isolates against 16 different antimicrobials.

\begin{tabular}{c|ccc}
\hline & \multicolumn{2}{c}{ Antimicrobial Resistance } & \\
\hline Antibiotic & $\begin{array}{c}\text { Chicken Livers } \\
\boldsymbol{n p / n}(\boldsymbol{\%})\end{array}$ & $\begin{array}{c}\text { Chicken Gizzards } \\
\boldsymbol{n p / n}(\boldsymbol{\%})\end{array}$ & $\begin{array}{c}\text { Chicken Livers and Gizzard } \\
\boldsymbol{n p / n}(\boldsymbol{\%})\end{array}$ \\
\hline azithromycin & $25 / 87(28.7)$ & $22 / 28(78.6)$ & $47 / 115(40.9)$ \\
\hline ciprofloxacin & $13 / 87(14.9)$ & $21 / 28(75.0)$ & $34 / 115(29.6)$ \\
\hline gentamicin & $10 / 87(11.5)$ & $2 / 28(7.1)$ & $12 / 115(10.4)$ \\
\hline oxacillin & $19 / 87(21.8)$ & $18 / 28(64.3)$ & $37 / 115(32.2)$ \\
\hline cefoxitin & $10 / 87(11.5)$ & $12 / 28(42.9)$ & $22 / 115(19.1)$ \\
\hline tetracycline & $59 / 87(67.8)$ & $23 / 28(82.1)$ & $82 / 115(71.3)$ \\
\hline vancomycin & $30 / 87(34.5)$ & $15 / 28(53.6)$ & $45 / 115(39.1)$ \\
\hline doxycycline & $49 / 87(56.3)$ & $24 / 28(85.7)$ & $73 / 115(63.5)$ \\
\hline trimethoprim/sulfamethoxazole & $22 / 87(25.3)$ & $6 / 28(21.4)$ & $28 / 115(24.3)$ \\
\hline clindamycin & $13 / 87(14.9)$ & $1 / 28(3.6)$ & $14 / 115(12.2)$ \\
\hline penicillin & $47 / 87(54.0)$ & $23 / 28(82.1)$ & $70 / 115(60.9)$ \\
\hline ampicillin & $83 / 87(95.4)$ & $19 / 28(67.9)$ & $102 / 115(88.9)$ \\
\hline kanamycin & $17 / 87(19.5)$ & $7 / 28(25.0)$ & $14 / 115(12.2)$ \\
\hline erythromycin & $31 / 87(35.6)$ & $21 / 28(75.0)$ & $52 / 115(45.2)$ \\
\hline rifampin & $25 / 87(28.7)$ & $2 / 28(7.1)$ & $27 / 115(23.5)$ \\
\hline chloramphenicol & $11 / 87(12.6)$ & $1 / 28(3.6)$ & $12 / 115(10.4)$ \\
\hline
\end{tabular}

*np: number of positive isolates, $n$ : number of isolates collected.

\subsection{Toxin Genes Possession Screening of the Recovered Isolates}

A total of 115 Staphylococcus aureus isolates (87 chicken liver isolates and 28 chicken gizzard isolates) were screened for eighteen different toxin genes that belong to six different toxin gene groups (Tables 3 and 6). As shown in Table 6, the prevalence of toxin genes in the 115 S. aureus isolates from chicken livers and gizzards to the eighteen tested toxin genes were as follow: hla (94.5\%), hld 
(94.5\%), hlb (48.7\%), sei (42.6\%), lukE-lukD (36.5\%), seg (29.6\%), seh (4.3\%), sed (0.9\%), sea (0\%), seb-sec (0\%), sec (0\%), see (0\%), sej (0\%), tst (0\%), eta (0\%), etb (0\%), lukM (0\%), and lukS-lukF $(0 \%)$. S. aureus hemolysin genes were found at a higher percentage in the chicken livers and gizzards than other groups of toxin genes screened. Also no isolates harbored enterotoxin genes sed, sea, seb$s e c, s e c$, see, or $s e j$, the toxic shock syndrome toxin 1 gene $t s t$, the exfoliative toxin genes $e t a$, etb, or the Leucocidin gene lukM (Table 6). The prevalence of enterotoxin genes seg $(71.43 \%$ ) and sei $(92.9 \%)$ in chicken gizzards was higher than in chicken livers, where seg was $16.1 \%$ and sei was $26.4 \%$. One isolate from chicken livers was positive for the entoretoxin gene sed (1.2\%) and 23/87 of chicken livers isolates were positive for the entoretoxin gene sei $(26.4 \%)$. The prevalence of hemolysin genes hla $(97.5 \%)$, hld (97.5\%) and hlb (64.4\%) in chicken livers was higher than in chicken gizzards when it was $85.7 \%, 85.7 \%$ and $0 \%$ respectively. The Hemolysin gene hlb was present only in the chicken livers. Both chicken livers and gizzards isolates had similar prevalence for lukE-lukD.

Table 6. The prevalence of 18 different toxin genes in the 115 Staphylococcus aureus chicken liver and gizzard isolates.

\begin{tabular}{|c|c|c|c|}
\hline \multicolumn{4}{|c|}{ Prevalence of Toxin Genes } \\
\hline Toxin Gene & $\begin{array}{c}\text { Chicken Livers } \\
n p / n(\%) *\end{array}$ & $\begin{array}{c}\text { Chicken Gizzards } \\
n p / n(\%) \\
\end{array}$ & $\begin{array}{c}\text { Chicken Livers and Gizzards } \\
n p / n(\%)\end{array}$ \\
\hline sea & $0 / 87(0)$ & $0 / 28(0)$ & $0 / 115(0)$ \\
\hline seb-sec & $0 / 87(0)$ & $0 / 28(0)$ & $0 / 115(0)$ \\
\hline sec & $0 / 87(0)$ & $0 / 28(0)$ & $0 / 115(0)$ \\
\hline sed & $1 / 87(1.2)$ & $0 / 28(0)$ & $1 / 115(0.9)$ \\
\hline see & $0 / 87(0)$ & $0 / 28(0)$ & $0 / 115(0)$ \\
\hline seg & $14 / 87(16.1)$ & $20 / 28(71.43)$ & $34 / 115(29.6)$ \\
\hline seh & $5 / 87(5.8)$ & $0 / 28(0)$ & $5 / 115(4.3)$ \\
\hline sei & $23 / 87(26.4)$ & $26 / 28(92.9)$ & $49 / 115(42.6)$ \\
\hline$s e j$ & $0 / 87(0)$ & $0 / 28(0)$ & $0 / 115(0)$ \\
\hline$t s t$ & $0 / 87(0)$ & $0 / 28(0)$ & $0 / 115(0)$ \\
\hline eta & $0 / 87(0)$ & $0 / 28(0)$ & $0 / 115(0)$ \\
\hline$e t b$ & $0 / 87(0)$ & $0 / 28(0)$ & $0 / 115(0)$ \\
\hline lukE-lukD & $32 / 87(36.8)$ & $10 / 28(35.7)$ & $42 / 115(36.5)$ \\
\hline$l u k M$ & 0/87 (0) & $0 / 28(0)$ & $0 / 115(0)$ \\
\hline hla & $85 / 87(97.7)$ & $24 / 28(85.7)$ & $109 / 115(94.5)$ \\
\hline$h l b$ & $56 / 87(64.4)$ & $0 / 28(0)$ & $56 / 115(48.7)$ \\
\hline hld & $85 / 87(97.7)$ & $24 / 28(85.7)$ & $109 / 115(94.5)$ \\
\hline lukS-lukF & $0 / 87(0)$ & $0 / 28(0)$ & $0 / 115(0 \%)$ \\
\hline
\end{tabular}

* $n p$ : number of positive isolates, $n$ : number of isolates collected.

The literature is lacking data related to the prevalence of toxin genes in $S$. aureus isolated from chicken livers and gizzards. Even recent studies discussing S. aureus in US retail poultry in general lacks such toxin genes prevalence data. A study in Japan reported that $25.3 \%$ of their chicken liver isolates were enterotoxigenic while $36.4 \%$ of their chicken gizzards produced enterotoxins [9]. Even though they have not used PCR to detect enterotoxin genes in the Japanese study, their chicken gizzards strains showed a higher prevalence of enterotoxins that their chicken livers ones which is in 
agreement with our findings. The higher prevalence of hemolysin genes in chicken livers isolates than in the chicken gizzards ones might be due to the availability of blood in the liver which might select for $S$. aureus strains with blood lysing abilities. Chicken livers and gizzards should be cooked thoroughly since enterotoxins of $S$. aureus are known for their heat tolerance. So even if the cooking temperature was high enough to kill the pathogen, enterotoxins produced on the chicken livers or gizzards could tolerate such temperature increasing the risk of food poisoning.

\subsection{Genotyping Using spa Typing}

A subset of Staphylococcus aureus recovered strains (6 from chicken livers, and 5 from chicken gizzards) were subjected to molecular typing by spa typing (Figure 1). As it is shown in Figure 1, spa types were grouped into two major clusters with the majority of isolates in each cluster belonging to one source. As it is also shown in figure 1, the tested isolates showed higher diversity in regards to their spa types since 7 different spa types were detected among a subset of 11 isolates. The detected spa types (t1081, t064, t002, and t091) were not known to be livestock associated and hence, maybe of a human origin [45]. This is in agreement with what we discussed earlier in the introduction section about that the origin of $S$. aureus strains detected in US retail meats is mostly of a human origin rather than livestock associated as it is the case in Europe.

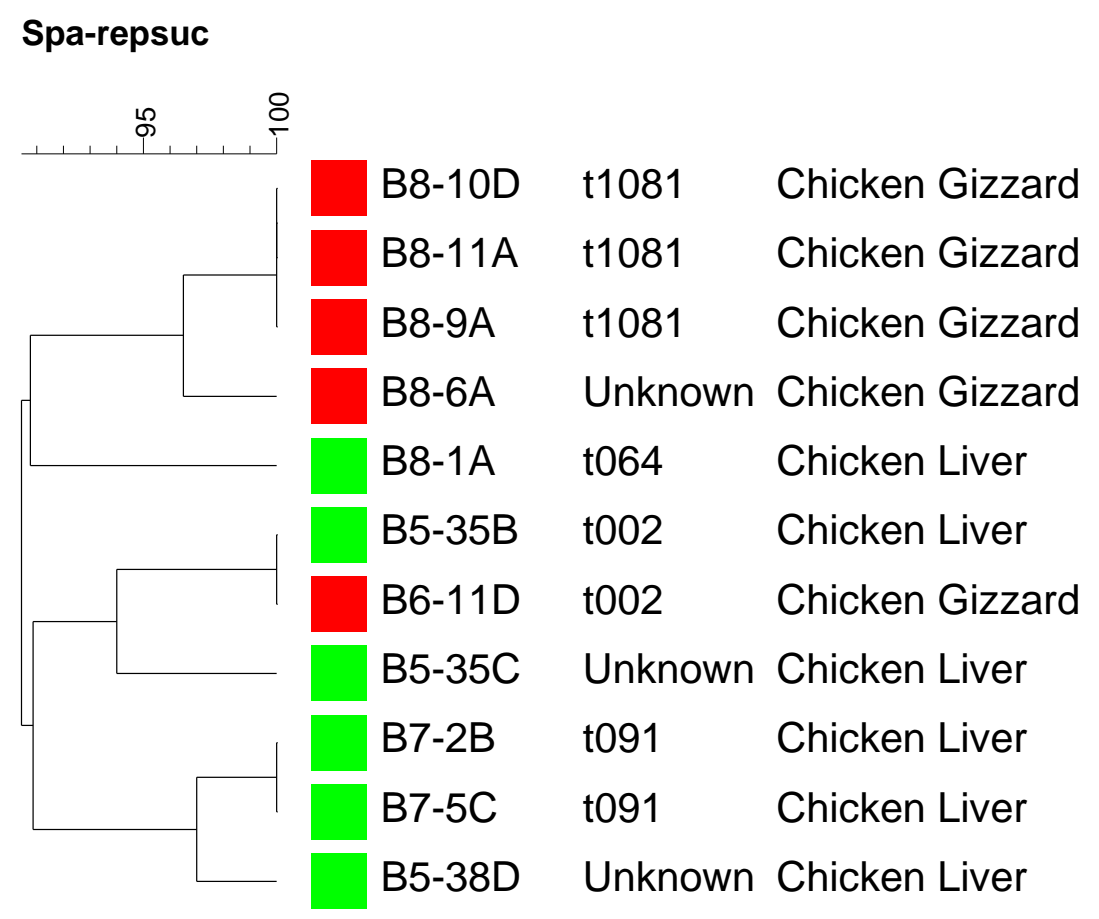

Figure 1. A dendrogram showing spa typing for a subset of the recovered Staphylococcus aureus strains representing chicken livers and chicken gizzards sources. Strains isolated from the same meat source are labeled by the same color square.

\section{Conclusions}

The prevalence of $S$. aureus in retail chicken livers and gizzards tested in this study varied between the two brands tested. While one of the brands showed very low prevalence of $S$. aureus, the second 
brand showed prevalence close to $37 \%$. The percentage of resistance to most of the antimicrobials screened was generally higher in isolates recovered from chicken gizzards. While no isolate harbored the mecA or mecC gene, a higher percentage of the chicken gizzards isolates were resistant to cefoxitin and/or oxacillin making them phenotypically similar to MRSA. A high percentage of $S$. aureus recovered strains particularly from chicken gizzards harbored enterotoxins seg and sei. The lucocidin genes $l u k E-l u k D$ was equally prevalent in chicken livers and gizzards isolates. The hemolysin $h l b$ gene was only prevalent in the chicken livers strains while $h l a$ and $h l d$ were prevalent in chicken livers and gizzards strains. Using spa typing, a subset of the recovered isolates showed that they are not known to be livestock associated and hence, maybe of a human origin. Data obtained from this study stress the importance of thorough cooking of chicken livers and gizzards since it might contain multidrug resistant enterotoxigenic $S$. aureus.

\section{Acknowledgments}

L. A. is grateful to the Libyan Government for financial support during her M.S. study in the US. The authors would like to acknowledge financial support from The University of Tulsa Office of Research and Sponsored Programs (The Student Research Grant Program) in subsidizing the purchase of the retail chicken livers and gizzards used in this study. The authors are also grateful to Peggy Hill for the English language editing of the manuscript.

\section{Author Contributions}

M. K. F. suggested and designed the experiments. L. A. performed the experiments. L. A. and M. K. F. wrote and revised the manuscript.

\section{Conflicts of Interest}

The authors declare no conflict of interest.

\section{References}

1. Noormohamed, A.; Fakhr, M.K. Incidence and antimicrobial resistance profiling of Campylobacter in retail chicken livers and gizzards. Foodborne Pathog. Dis. 2012, 9, 617-624.

2. Little, C.L.; GormLy, F.J.; Rawal, N.; Richardson, J.F. A recipe for disaster: Outbreaks of campylobacteriosis associated with poultry liver pâté in England and Wales. Epidemiol. Infect. 2010, 138, 1691-1694.

3. Abid, M.; Wimalarathna, H.; Mills, J.; Saldana, L.; Pang, W.; Richardson, J.F.; Martin, C.J.M.; McCarthy, N.D. Duck liver-associated outbreak of campylobacteriosis among humans, United Kingdom, 2011. Emerg. Infect. Dis. 2013, 19, 1310.

4. O’Leary, M.C.; Harding, O.; Fisher, L.; Cowden, J. A continuous common-source outbreak of campylobacteriosis associated with changes to the preparation of chicken liver pâté. Epidemiol. Infect. 2009, 137, 383-388. 
5. Forbes, K.J.; GormLey, F.J.; Dallas, J.F.; Labovitiadi, O.; MacRae, M.; Owen, R.J.; Richardson, J.; McGuigan, C.C. Campylobacter immunity and coinfection following a large outbreak in a farming community. J. Clin. Microbiol. 2009, 47, 111-116.

6. Centers for Disease Control and Prevention (CDC). Multistate outbreak of Campylobacter jejuni infections associated with undercooked chicken livers-Northeastern United States, 2012. Morb. Mortal. Wkly. Rep. 2013, 62, 874.

7. Terry, L. Outbreak Tied to Chicken Livers: 6 Sick, High-End Restaurants "Mortified". Available online: http://www.oregonlive.com/health/index.ssf/2014/02/post_85.html (accessed on 12 August 2014).

8. Centers for Disease Control (CDC). Multistate Outbreak of Human Salmonella Heidelberg Infections Linked to "Kosher Broiled Chicken livers" from Schreiber Processing Corporation. Available online: http://www.cdc.gov/salmonella/heidelberg-chickenlivers/011112/index.htmL (accessed on 12 August 2014).

9. Kitai, S.; Shimizu, A.; Kawano, J.; Sato, E.; Nakano, C.; Uji, T.; Kitagawa, H. Characterization of methicillin-resistant Staphylococcus aureus isolated from retail raw chicken meat in Japan. J. Vet. Med. Sci. 2005, 67, 107-110.

10. Gundogan, N.; Citak, S.; Yucel, N; Devren, Y.A. A note on the incidence and antibiotic resistance of Staphylococcus aureus isolated from meat and chicken samples. Meat Sci. 2005, 69, 807-810.

11. Centers for Disease Control (CDC). CDC Estimates of Foodborne Illness in the United States, 2011. Available online: http://www.cdc.gov/foodborneburden/2011-foodborne-estimates.htmL (accessed on 16 May 2013).

12. Genigeorgis, C.A. Present state of knowledge on staphylococcal intoxication. Int. J. Food Microbiol. 1989, 9, 327-360.

13. Zschöck, M.; Kloppert, B.; Wolter, W.; Hamann, H.P.; LämmLer, C. Pattern of enterotoxin genes seg, seh, sei and sej positive Staphylococcus aureus isolated from bovine mastitis. Vet. Microbiol. 2005, 108, 243-249.

14. Ono, H.K.; Omoe, K.; Imanishi, K.; Iwakabe, Y.; Hu, D.L.; Kato, H.; Saito, N.; Nakane, A.; Uchiyama, T.; Shinagawa, K. Identification and characterization of two novel staphylococcal enterotoxin, types S and T. Infect. Immunol. 2008, 76, 4999-5005.

15. Wang, S.C.; Wu, C.M.; Xia, S.C.; Qi, Y.H.; Xia, L N.; Shen, J.Z. Distribution of superantigenic toxin genes in Staphylococcus aureus isolates from milk samples of bovine subclinical mastitis cases in two major diary regions of China. Vet. Microbiol. 2009, 137, 276-281.

16. Argudín, M.A.; Mendoza, M.C.; Rodicio, M.R. Food poisoning and Staphylococcus aureus enterotoxins. Toxins 2010, 2, 1751-1773.

17. Burnside, K.; Lembo, A.; de los Reyes, M.; Iliuk, A.; Binhtran, N.-T.; Connelly, J.E.; Lin, W.-J.; Schmidt, B.Z.; Richardson, A.R.; Fang, F.C.; et al. Regulation of hemolysin expression and virulence of Staphylococcus aureus by a serine/threonine kinase and phosphatase. PLoS ONE 2010, 5, e11071.

18. O’Callaghan, R.J.; Callegan, M.C.; Moreau, J.M.; Green, L.C.; Foster, T.J.; Hartford, O.M.; Engel, L.S.; Hill, J.M. Specific roles of alpha-toxin and beta-toxin during Staphylococcus aureus corneal infection. Infect. Immun. 1997, 65, 1571-1578. 
19. Kim, C.S.; Jeon, S.Y.; Min, Y.G.; Rhyoo, C.; Kim, J.W.; Yun, J.B.; Park, S.W.; Kwon, T.Y. Effects of betatoxin of Staphylococcus aureus on ciliary activity of nasal epithelial cells. Laryngoscope 2000, 110, 2085-2088.

20. Hayashida, A.; Bartlett, A.H.; Foster, T.J.; Park, P.W. Staphylococcus aureus betatoxin induces lung injury through syndecan-1. Am. J. Pathol. 2009, 174, 509-518.

21. De Neeling, A.J.; van Leeuwen, W.J.; Schouls, L.M.; Schot, C.S.; van Veen-Rutgers, A.; Beunders, A.J.; Buiting, A.G.; Hol, C.; Ligtvoet, E.E.; Petit, P.L.; et al. Resistance of staphylococci in The Netherlands: Surveillance by an electronic network during 1989-1995. J. Antimicrob. Chemoth. 1998, 41, 93-101.

22. Khanna, T.; Friendship, R.; Dewey, C.; Weese, J.S. Methicillin resistant Staphylococcus aureus colonization in pigs and pig farmers. Vet. Microbiol. 2008, 128, 298-303.

23. Voss, A.; Loeffen, F.; Bakker, J.; Klaassen, C.; Wulf, M. Methicillin resistant Staphylococcus aureus in pig farming. Emerg. Infect. Dis. 2005, 11, 1965-1966.

24. Van den Eede, A.; Hermans, K.; Lipinska, U.; Struelens, M.; Deplano, A.; Denis, O.; Gasthuys, F.; Haesebrouck, F.; Martens, A. Nasal carriage of methicillin-resistance Staphylococcus aureus in the equine population: Prevalence, typing and antimicrobial resistance, p. 20. In Proceedings of the 2nd Symposium on Antimicrobial Resistance in Animals and the Environment, ARAE-2007, Tours, France, 17-19 December 2007.

25. De Boer, E.; Zwartkruis-Nahuis, J.T.M.; Wit, B.; Huijsdens, X.W.; de Neeling, A.J.; Bosch, T.; van Oosterom, R.A.A.; Vila A.; Heuvelink, A.E. Prevalence of methicillin-resistant Staphylococcus aureus in meat. Int. J. Food Microbiol. 2009, 134, 52-56.

26. Buyukcangaz, E.; Velasco, V.; Sherwood, J.S.; Stepan, R.M.; Koslofsky, R.J.; Logue, C.M. Molecular typing of Staphylococcus aureus and methicillin-resistant S. aureus (MRSA) isolated from animals and retail meat in North Dakota, United States. Foodborne Pathog. Dis. 2013, 10, 608-617.

27. Velasco, V.; Sherwood, J.S.; Rojas-García, P.P.; Logue, C.M. Multiplex real-time PCR for detection of Staphylococcus aureus, mecA and Panton-Valentine Leukocidin (PVL) genes from selective enrichments from animals and retail meat. PloS ONE 2014, 9, e97617.

28. Jackson, C.R.; Davis, J.A.; Barrett, J.B. Prevalence and characterization of methicillin-resistant Staphylococcus aureus isolates from retail meat and humans in Georgia. J. Clin. Microbiol. 2013, 51, 1199-1207.

29. O’Brien, A.M.; Hanson, B.M.; Farina, S.A.; Wu, J.Y.; Simmering, J.E.; Wardyn, S.E.; Smith, T.C. MRSA in conventional and alternative retail pork products. PLoS ONE 2012, 7, e30092.

30. Hanson, B.M.; Dressler, A.E.; Harper, A.L.; Scheibel, R.P.; Wardyn, S.E.; Roberts, L.K.; Smith, T.C. Prevalence of Staphylococcus aureus and methicillin-resistant Staphylococcus aureus (MRSA) on retail meat in Iowa. J. Infect. Public Health 2011, 4, 169-174.

31. Bhargava, K.; Wang, X.; Donabedian, S.; Zervos, M.; da Rocha, L.; Zhang, Y. Methicillinresistant Staphylococcus aureus in retail meat, Detroit, Michigan, USA. Emerg. Infect. Dis. 2011, $17,1135$.

32. Kelman, A.; Soong, Y.A.; Dupuy, N.; Shafer, D.; Richbourg, W.; Johnson, K.; Meng, J. Antimicrobial susceptibility of Staphylococcus aureus from retail ground meats. J. Food Prot. 2011, 74, 1625-1629. 
33. Pu, S.; Wang, F.; Ge, B. Isolation and characterization of methicillin-resistant Staphylococcus aureus strains from Louisiana retail meats. Appl. Environ. Microb. 2009, 75, 265-267.

34. Martineau, F.; Picard, F.J.; Roy, P.H.; Ouellette, M.; Bergeron, M.G. Species-specific and ubiquitous-DNA-based assays for rapid identification of Staphylococcus aureus. J. Clin. Microbiol. 1998, 36, 618-623.

35. Murakami, K.; Minamide, W.; Wada, K.; Nakamura, E.; Teraoka, H.; Watanabe, S. Identification of methicillin-resistant strains of staphylococci by polymerase chain reaction. J. Clin. Microbiol. 1991, 29, 2240-2244.

36. Alvarez, L.G.; Holden, M.T.G.; Lindsay, H.; Webb, C.R.; Brown, D.F.J.; Curran, M.D.; Walpole, E.; Brooks, K.; Pickard, D.J.; Teale, C.; et al. Methicillin-resistant Staphylococcus aureus with a novel mecA homologue in human and bovine populations in the UK and Denmark: A descriptive study. Lancet 2011, 11, 595-603.

37. Shore, A.C.; Deasy, E.C.; Slickers, P.; Brennan, G.; Connell, B.O.; Monecke, S.; Ehricht, R.; Coleman, D.C. Detection of staphylococcal cassette chromosome mec Type XI carrying highly divergent mecA, mecI, mecRl, blaZ, and ccr genes in human clinical isolates of clonal complex 130 Methicillin-Resistant Staphylococcus aureus. Antimicrob. Agents Chemother. 2011, 55, 37653773.

38. Marmur, J. A procedure for the isolation of deoxyribonucleic acid from microorganisms. J. Mol. Bio. 1961, 3, 298-218.

39. Clinical and Laboratory Standards Institute. Performance Standards for Antimicrobial Susceptibility Testing; Twenty-First Informational Supplement. CLSI 2011, 31, 1-172.

40. Monday, S.R.; Bohach, G.A. Use of multiplex PCR to detect classical and newly described pyrogenic toxin genes in staphylococcal isolates. J. Clin. Microbiol. 1999, 37, 3411-3414.

41. Mehrotra, M.; Wang, G.; Johnson, W.M. Multiplex PCR for detection of genes for Staphylococcu aureus enterotoxins, exfoliative toxins, toxic shock syndrome toxin 1, and methicillin resistance. J. Clin. Microbiol. 2000, 38, 1032-1035.

42. Jarraud, S.; Mougel, C.; Thioulouse, J.; Lina, G.; Meugnier, H.; Forey, F.; Nesme, X.; Etienne, J.; Vandenesch, F. Relationships between Staphylococcus aureus genetic background, virulence factors, agr groups (alleles), and human disease. Infect. Immun. 2002, 70, 631-641.

43. Shopsin, B.; Gomez, M.; Montgomery, S.O.; Smith, D.H.; Waddington, M.; Dodge, D.E.; Bost, D.E.; Riehman, M.; Naidich, S.; Kreiswirth, B.N. Evaluation of protein A gene polymorphic region DNA sequencing for typing of Staphylococcus aureus strains. J. Clin. Microbiol. 1999, 37, 3556-3563.

44. Pereira, V.; Lopes, C.; Castro, A.; Silva, J.; Gibbs, P.; Teixeira, P. Characterization for enterotoxin production, virulence factors, and antibiotic susceptibility of Staphylococcus aureus isolates from various foods in Portugal. Food Microbiol. 2009, 26, 278-282.

45. Hetem, D.J.; Bootsma, M.C.; Troelstra, A.; Bonten, M.J. Transmissibility of livestock-associated methicillin-resistant Staphylococcus aureus. Emerg. Infect. Dis. 2013, 19, 1797.

(C) 2015 by the authors; licensee MDPI, Basel, Switzerland. This article is an open access article distributed under the terms and conditions of the Creative Commons Attribution license (http://creativecommons.org/licenses/by/4.0/). 